\title{
From the Mantle to Mineralisation: the Cobalt Story
}

\author{
A.E. WILLIAMS-JONES* AND O.V. VASYUKOVA
}

McGill University, Montreal, QC, H3A 0E8, Canada

(*correspondence: anthony.williams-jones@ mcgill.ca)

Technological advances, notably the development of CoLi-ion batteries, have created a huge demand for cobalt that will continue as electrically-driven vehicles replace vehicles driven by the internal combustion engine. The main reservoir for cobalt is the mantle where it is stored in olivine and, owing to this compatibility, its content is highest in komatiitic magmas. Economic concentrations of cobalt (>1000 ppm) may develop, if these magmas exsolve sulphide liquids, into which cobalt partitions strongly. Oxidised brines, in which cobalt dissolves as chloride complexes, play an important role in the concentration of cobalt. We propose that this was the case in the Democratic Republic of the Congo, which supplies $\sim 50 \%$ of the World's cobalt. There, evaporitederived brines interacted with mafic-ultramafic basement complexes, leaching $\mathrm{Co}$ (and $\mathrm{Cu}$ ) via chloride-complexation and depositing them as sulphides (mainly carrolite $\left[\mathrm{CuCo}_{2} \mathrm{~S}_{4}\right]$ ) in response to reduction, to produce stratiform diagenetic deposits in the overlying organic carbon-bearing siliciclastic and carbonate sediments. The only primary cobalt deposits currently being mined comprise arsendide ores in veins and lenses along the contacts of serpentinite with felsic to intermediate intrusions and volcanic rocks, in the Bou Azzer district, Morocco. We propose that the Co was leached from magnetite in the serpentinites by oxidised, midly acidic, arsenate- and sulphate-bearing evaporite-derived brines that were mobilised during the Hercynian orogenty. At the sites of deposition, these fluids caused intense alteration of the serpentinite to talc and the intrusive/volcanic rocks to chlorite. Arsenide (skutterudite [ $\left.\mathrm{CoAs}_{3}\right]$ and safflorite [CoAs 2$]$ ) and sulfarsenide (cobaltite [CoAsS]) mineral deposition ensued in response to the resulting increase in $\mathrm{pH}$, a mild reduction of $f \mathrm{O}_{2}$ and the high As to reduced $\mathrm{S}$ ratio of the fluid. At ambient temperature, Co is concentrated in the limonitic zone of laterites during the weathering of ultramafic rocks. We propose that it is mobilised as $\mathrm{Co}^{2+}$ and concentrated as heterogenite $[\mathrm{CoOOH}]$ on the attainment of an optimum combination of $\mathrm{pH}$ increase and $\mathrm{fO}_{2}$ decrease during the downward percolation of the weathering fluids. In summary, Co is mobilised from the mantle reservoir by komatiitic magmas and concentrated to mineable levels in the crust by sulphide-silicate liquid immiscibility, hydrothermal processes and weathering. 